\title{
The Role of Connexin 37 Polymorphism in Spontaneous Abortion
}

\author{
Michal KNÍŽE ${ }^{1}$, Jan PIŤHA ${ }^{2}$, Jaroslav A. HUBACEK ${ }^{2,4}$ Tomáš FAIT $^{1}$ \\ ${ }^{1}$ Department of Obstetrics and Gynecology, Motol University Hospital, Prague, Czech Republic, \\ ${ }^{2}$ Centre for Experimental Medicine, Institute of Clinical and Experimental Medicine, Prague, Czech \\ Republic, ${ }^{3}$ Department of Cardiology, Institute of Clinical and Experimental Medicine, Prague, \\ Czech Republic, ${ }^{4}$ Third Department of Internal Medicine, First Faculty of Medicine, Charles \\ University, Prague, Czech Republic
}

Received August 29, 2020

Accepted March 1, 2021

Epub Ahead of Print May 12, 2021

\begin{abstract}
Summary
Among unique cardiovascular risk factors in women are complications during pregnancy, including miscarriage. Important risk factor is also genetic background. One of powerful candidate genes for cardiovascular disease of atherosclerotic origin (aCVD) is gene for connexin 37 (Cx37) with strong gene-environment interaction including smoking status, that is also strong risk factor for complications in pregnancy including spontaneous abortion (SA). We analyzed association between SA and $C \times 37$ gene polymorphism (1019C $>\mathrm{T}$; Pro319Ser) in 547 fetuses and its potential interaction with smoking status of mothers. Using genetic analyses from women from general population as controls, ORs for T allele, found in our previous studies to be protective against $\mathrm{aCVD}$, were calculated. T allele carriers (fetuses), had OR 0.91 (95\% CI 0.72-1.14) and no interaction with smoking was observed. In conclusion, no significant association between $C \times 37$ polymorphism and SA was observed and no modifying effect of smoking status on this association was detected.
\end{abstract}

\section{Key words}

Connexin 37 gene - Gap junctions - Spontaneous abortion • Protective factor $\bullet$ Smoking $\bullet$ Cardiovascular disease • Candidate genes

\section{Corresponding author}

M. Kniže, Department of Obstetrics and Gynecology, Motol University Hospital, V Úvalu 84/1, 15006 Prague 5, Czech Republic. E-mail: michal.knize@gmail.com
Regarding cardiovascular disease of atherosclerotic origin (aCVD) the annual incidence of cardiovascular diseases is age-dependently increasing both in men and women. The prevalence is higher in men until midlife (Kittnar 2020). However, women are affected similarly or more than men in older age. Despite the main cardiovascular factors are shared by both sexes, several unique cardiovascular factors were described in women as is miscarriage and other complications during pregnancy (Horn et al. 2019, Oliver-Williams et al. 2013) and metabolic disorders as gestational diabetes mellitus (Vejrazkova et al. 2017). Therefore, detection of determinants of atherosclerotic disease in women including metabolic ones may help to identify and to prevent atherosclerotic process and its clinical complications (Pithová et al. 2016). However, also better understanding of the complications in pregnancy might have similar preventative effect especially when accompanied by genetic analyses. Indeed, genetic studies could help to identify not only inherited causes of early pregnancy loss, extremely serious and emotional problem both for affected women, their partners and their physicians, but also for aCVD. One of powerful candidate genes for aCVD is gene for connexin 37 $(\mathrm{C} 1019>\mathrm{T}) \quad(\mathrm{Cx} 37)$ with strong gene-environment interaction including smoking status. Connexins are the main proteins in gap junctions. Connexin 37 (Gap junction protein alpha; OMIM ID 121012; Cx37) is the main gap junction representative in the vessel wall 
expressed in endothelial cells, smooth muscle cells but also in monocytes (Chanson et al. 2007, Wong et al. 2006), therefore in the main cells involved in the process of atherosclerosis. Gene polymorphism-association studies have detected a link between the C1019>T single nucleotide polymorphism (SNP) in the human $C x 37$ gene and its protective role in cardiovascular disease. This polymorphism results in a non-conservative amino acid change in the regulatory $\mathrm{C}$-terminus of the $\mathrm{Cx} 37$ protein (P319>S). It was recently demonstrated that $\mathrm{Cx} 37$ hemichannels control the initiation of atherosclerotic plaque development by regulating ATP-dependent monocyte adhesion (Deroutte et al. 2009).

In addition to cells responsible for atherosclerosis and aCVD, Cx 37 is also present in ovary, in which gap junctions mediate metabolic cooperation between granulosa cells and oocyte. These interactions are mediated not only by paracrine factors but also by gap junctions including Cx37 (Fontana et al. 2020). Preimplantation embryos express multiple connexins and assemble them into gap junctions. The suppression of connexin expression seems to play an important role in embryo implantation in several species. The gap junction induction is one of the earliest known signs for a blastocyst-derived signal, which may be involved in preparing the endometrium for implantation. It could help to regulate the invasion process by a coordinated cell death of the endometrial cells replaced by the invading trophoblast (Grümmer and Winterhager 1998). However, despite the importance of the different connexin channels expressed in the endometrium this topic was not evaluated.

Based on these facts, we analyzed data from fetuses from women with spontaneous abortion (SA) for Cx37 gene polymorphism (1019C $>\mathrm{T}$; Pro319Ser) including its potential interaction with smoking, frequent risk factor for early pregnancy loss. In particular, we analyzed if $\mathrm{T}$ allele of $\mathrm{Cx} 37$ gene, found to be protective against ischemic heart disease in our previous studies, could be protective also against SA and if this protection could be modified by smoking status.

Women with verified diagnosis of SA participated in the study after giving written informed consent. The study was approved by the Institutional ethics committees and was conducted according to the Good Clinical Practice guidelines. Participating women filled in questionnaire focused on history of SA and physical and ultrasound examination were performed. Samples of aborted fetuses from Caucasian women $(n=547)$ aged 15-44 years (mean age $32.1 \pm 4.8$ years) collected during
2008-2011 at the Gynecological and Obstetrical Clinic in Prague (Rynekrova et al. 2012, Hubacek et al. 2015) were examined. Material acquired from surgical revision of uterine cavity was subjected to a cytogenetic and histological examination. Women with anatomic abnormalities of the uterus, primary endocrinopathies (such as thyreopathy, diabetes mellitus, hyperprolactinemia), known immunologic or hematologic disease, febrile infections during the first trimester, drug abuse and abnormal cytogenetic examination of the aborted tissue were excluded from the study.

As a control group we used data from the cohort of 662 women examined from the population sample in Prague (mean age 57.9 \pm 2.8 years). Detailed questionnaire about medical history, focused also on gynecological history including history of SA was obtained (Hubacek et al. 2009).

Samples from both groups of women (meant fetuses in study group) were stored at $-20^{\circ} \mathrm{C}$ and DNA was isolated by standard procedures. To genotype the Cx37 rs1764391 polymorphism, oligonucleotides 5'-CTGGACCCACCCCCTCAGAATGGCCAAAGA and 5'-AGGAAGCCGTAGTGCCTGGTGG and the restriction enzyme AasI (Fermentas, Lithuania) were used. $\mathrm{T}$ allele is characterized by restriction fragments $240 \mathrm{bp}+35 \mathrm{bp}$; and $\mathrm{C}$ allele with the unrestricted $275 \mathrm{bp}$ fragment. Restriction fragments were separated via electrophoresis using $2 \%$ agarose gel (Pitha et al. 2016b).

We compared the prevalence of $C \times 37$ gene variants (TT, CT, CC) between aborted material from women with SA vs. women from general population after stratifying them by smoking status (self-reported). Continuous variables were compared by unpaired Student's $t$-test (between study population and control group), for categorical variables $\chi^{2}$ Fischer exact test was used.

In women with spontaneous abortion $5.6 \%$ were smokers/past smokers (mean age 27.2 \pm 6.5 years) and $94.4 \%$ were non-smokers (mean age $32.3 \pm 4.6$ years) (difference for age, $\mathrm{p}<0.001$ ). In the population sample $44.8 \%$ women were smokers/past smokers (mean age $57 \pm 2.7$ years) and $55.2 \%$ non-smokers (mean age $57 \pm 2.7$ years).

Cx37 T allele was present in $55.2 \%$ (mean age $32.1 \pm 4.7$ years) of aborted fetuses, and in $57.5 \%$ (mean age $57 \pm 2.7$ years) of women from general population. In smoking women at least one $\mathrm{T}$ allele was present in $53.4 \%$ of the fetuses, and in $56.1 \%$ of women from 
general population. In non-smoking women at least one $\mathrm{T}$ allele was present in $55.1 \%$ of the fetuses, and in $59.0 \%$ of women from general population. We compared distribution of $C x 37$ gene polymorphism between fetuses from women older than 32 years with women younger than 32 years (median age). No difference in the prevalence of $\mathrm{T}$ allele was detected (56.9\% vs. $54.2 \%$, $\mathrm{p}=0.294)$. We also tested difference in prevalence of $\mathrm{T}$ allele between fetuses of women with one SA $(n=448)$ and fetuses of women with more than 1 SA $(n=115)$, but also in this case no significant difference was detected ( $54.3 \%$ vs. $60.0 \%, \mathrm{p}=0.161$ ). The only difference found was that women with more than one SA were older than women with one SA $(34.1 \pm 4.7$ vs. $31.6 \pm 4.8$ years, $\mathrm{p}<0.001)$. In addition, in the control group from general population, women (after exclusion of diabetics) with the history of one or more SA $(n=51)$ were compared to women without history of SA with history of pregnancy $(n=233)$ of similar age, no difference in the presence of $\mathrm{T}$ allele was observed (66.7 \% vs. $60.1 \%$; $\mathrm{p}=0.671)$.

Using general population as a control sample, ORs for $\mathrm{T}$ allele carriers were calculated for the whole populations under study and for smoking and nonsmoking women including similar stratification to smokers/past smokers and non-smokers as in the control group. Fetuses from women suffering from SA with T allele have OR 0.91 (95\% CI 0.72-1.14) and there was no interaction with smoking status of mothers, OR 0.84 (0.64-1.11) for non-smokers vs. OR 0.89 (0.42-1.9) for smokers (Table 1).

Table 1. Cx37 polymorphism in fetuses and population control. Smoking status in fetuses correspond with this characteristics in mothers.

\begin{tabular}{|c|c|c|c|c|c|c|}
\hline \multicolumn{7}{|c|}{ Entire groups } \\
\hline \multirow[t]{2}{*}{ Cx37 } & \multicolumn{2}{|c|}{ Controls } & \multicolumn{2}{|c|}{ Abortions } & \multirow[t]{2}{*}{ OR } & \multirow[t]{2}{*}{$\mathbf{P}$} \\
\hline & $\mathrm{N}$ & $\%$ & $\mathrm{~N}$ & $\%$ & & \\
\hline$C C$ & 281 & 42.5 & 239 & 44.8 & 1.00 & \\
\hline$C T$ & 300 & 45.3 & 239 & 44.8 & $0.93(0.73-1.19)$ & 0.28 \\
\hline$T T$ & 81 & 12.2 & 55 & 10.4 & $0.80(0.54-1.18)$ & 0.25 \\
\hline$+T$ & 381 & 57.5 & 294 & 55.2 & $0.91(0.72-1.14)$ & 0.41 \\
\hline \multicolumn{7}{|c|}{ Smokers/past smokers } \\
\hline \multirow[t]{2}{*}{ Cx37 } & \multicolumn{2}{|c|}{ Controls } & \multicolumn{2}{|c|}{ Abortions } & OR & $\mathbf{P}$ \\
\hline & $\mathrm{N}$ & $\%$ & $\mathrm{~N}$ & $\%$ & & \\
\hline$C C$ & 126 & 43.9 & 14 & 46.7 & 1.00 & \\
\hline$C T$ & 121 & 42.2 & 14 & 46.7 & $1.04(0.48-2.28)$ & 0.92 \\
\hline$T T$ & 40 & 13.9 & 2 & 6.7 & $0.45(0.10-2.07)$ & 0.29 \\
\hline$+T$ & 161 & 56.1 & 16 & 53.4 & $0.89(0.42-1.90)$ & 0.77 \\
\hline \multicolumn{7}{|c|}{ Neversmokers } \\
\hline \multirow[t]{2}{*}{ Cx37 } & \multicolumn{2}{|c|}{ Controls } & \multicolumn{2}{|c|}{ Abortions } & OR & $\mathbf{P}$ \\
\hline & $\mathrm{N}$ & $\%$ & $\mathrm{~N}$ & $\%$ & & \\
\hline$C C$ & 144 & 40.7 & 232 & 44.9 & 1.00 & \\
\hline$C T$ & 172 & 48.6 & 231 & 44.7 & $0.83(0.63-1.11)$ & 0.21 \\
\hline$T T$ & 38 & 10.4 & 54 & 10.4 & $0.88(0.55-1.40)$ & 0.28 \\
\hline$+T$ & 210 & 59.0 & 285 & 55.1 & $0.84(0.64-1.11)$ & 0.22 \\
\hline
\end{tabular}

In summary, in our study we found no significant differences in $C x 37$ gene variability between fetuses analyzed after SA and general population of middle aged women. These results were not modified by smoking status. Therefore, in contrast to our previous findings in women with acute coronary syndrome (Pitha 
et al. 2016a) $\mathrm{T}$ allele does not seem to be neither protective against SA, nor its effect is strongly modified by smoking status. Therefore, mechanisms leading to cardiovascular disease and complications during pregnancy including SA seems to be different regarding mechanism mediated by gap junctions involved in differentiation processes by mediating exchanges between mother and fetus cells, affecting the maternofetal blood flow interrelationships, trophoblast invasiveness and the formation of a syncytiotrophoblast (Malassiné and Cronier 2005). Expression of some connexins, among them also $\mathrm{Cx} 37$, has been shown to reflect maturity of luteinized follicles in animal models and $\mathrm{Cx} 43$ expression was associated with better prognosis in in vitro fertilization (Tsai et al. 2003). Transcription factors of several connexins were detected in human embryos, e.g. Cx43 was indicated in all embryonic developing stages (Bloor et al. 2004). He and Chen (2016) demonstrated that the expression of $\mathrm{Cx} 43$, together with VEGF, is significantly reduced in chorionic villi and decidua in women with spontaneous abortion. This may be caused by the influence on angiogenesis of placenta and developing embryo. It was reported (Togashi et al. 2015), that mouse embryos cultured with some gap junctions inhibitors presented frequent collapses and developmental delay. Functional and structural abnormalities of $\mathrm{Cx} 43$ might also play an important role in heart diseases (Pecoraro et al. 2015). Because of this finding and possible similarity with Cx43, we focused on Cx37 polymorphism on spontaneous abortion. In addition, $C x 37$ polymorphism is also supposed to play important role in cardiovascular events. Nevertheless, we did not found an association in the case of $C x 37$ gene as for other studies describing different connexins polymorphisms and spontaneous abortion (He and Chen 2016).

Regarding the (absence of) effect of smoking in our study, the idea was that adhesion properties of vessels wall caused by $C x 37$ gene polymorphism could favor not only macrophage accumulation in the atherosclerotic lesions but also endothelial dysfunction induced by smoking initiated by reduced nitric oxide bioavailability and further by the increased expression of adhesion molecules (Messner et al. 2014) Therefore protective effect of the $C \times 37 \mathrm{~T}$ allele might be strongly modified by smoking in atherosclerosis. But according to our data the deleterious effect of smoking on pregnancy, particularly on SA seems not to be mediated through $C x 37$ gene.

The limitations of our study are incomplete data in women with history of SA and focus only on one polymorphism of one gene from rather large connexin family. On the other hand, the strengths of the study include high number of studied women and numerous representative control group from the population sample in Prague, which could reflect real population background for our findings in contrast to cases and controls usually used for such comparisons. In addition, selecting only Cx37 gene was based on knowledge, that connexin 37 is on one hand the main protein of gap junctions in cells involved in the process of atherosclerosis, but on the other hand it is also present in maternofetal organs. Moreover, data from the Czech Republic, Croatia, Hungary and Romania indicated that the strongest protective effect of the $C x 37 \mathrm{~T}$ allele was detected in the non-smoking patients without diabetes mellitus and hypertension and that effect could be mediated through stem cells (Pitha et al. 2010, Pitha et al. 2016a). Therefore, we have chosen Cx37 polymorphism as gene potentially covering both cardiovascular and pregnancy complications. Another limitation is the lack of data from mothers/fathers and absence of information regarding other potential modifying factors including diabetes mellitus; however, women with these characteristics were excluded to detect only the effect of this particular gene variability and smoking.

In summary, to the best of our knowledge, only a few studies have demonstrated effect of connexins on spontaneous abortion and no studies analyzed parallel effect of particular connexin gene polymorphism on cardiovascular disease and SA. In our study, no effect of Cx37 polymorphism measured in fetuses was observed on abortion and no interaction with smoking status on this association was proved.

\section{Conflict of Interest}

There is no conflict of interest.

\section{Acknowledgements}

This work was supported by Supported by the project (Ministry of Health, Czech Republic) for development of research organization 00023001 (IKEM, Prague, Czech Republic) and 00064203 (Motol University Hospital, Prague, Czech Republic).

\footnotetext{
Abbreviations

aCVD - Cardiovascular disease of atherosclerotic origin, CI - Confidence interval, Cx37 - Connexin 37, DNA Deoxyribonucleic acid, OR - Odds ratio, SA Spontaneous abortion, VEGF - Vascular endothelial growth factor.
} 


\section{References}

BLOOR DJ, WILSON Y, KIBSCHULL M, TRAUB O, LEESE HJ, WINTERHAGER E, KIMBER SJ: Expression of connexins in human preimplantation embryos in vitro. Reprod Biol Endocrinol 2: 25, 2004. https://doi.org/10.1186/1477-7827-2-25

CHANSON M, KWAK BR: Connexin37: a potential modifier gene of inflammatory disease. J Mol Med 85: 787-795, 2007. https://doi.org/10.1007/s00109-007-0169-2

DEROUETTE JP, DESPLANTEZ T, WONG CW, ROTH I, KWAK BR, WEINGART R: Functional differences between human Cx37 polymorphic hemichannels. J Mol Cell Cardiol 46: 499-507, 2009. https://doi.org/10.1016/j.yjmcc.2008.12.018

FONTANA J, MARTINKOVA S, PETR J, ZALMANOVÁ T, TRNKA J: Metabolic cooperation in the ovarian follicle. Physiol Res 69: 33-48, 2020. https://doi.org/10.33549/physiolres.934233

GRÜMMER R, WINTERHAGER E: Regulation of gap junction connexins in the endometrium during early pregnancy. Cell Tissue Res 293: 189-194, 1998. https://doi.org/10.1007/s004410051111

HE X, CHEN Q: Reduced expressions of connexin 43 and VEGF in the first-trimester tissues from women with recurrent pregnancy loss. Reprod Biol Endocrinol 14: 46, 2016. https://doi.org/10.1186/s12958-016-0179-4

HORN J, TANZ LJ, STUART JJ, MARKOVITZ AR, SKURNIK G, RIMM EB, MISSMER SA, RICH-EDWARDS JW: Early or late pregnancy loss and development of clinical cardiovascular disease risk factors: a prospective cohort study. BJOG 126: 33-42, 2019. https://doi.org/10.1111/1471-0528.15452

HUBACEK JA, PITHA J, ADAMKOVA V, LANSKA V, POLEDNE R: A common variant in the FTO gene is associated with body mass index in males and postmenopausal females but not in premenopausal females. Czech postMONICA and 3PMFs studies. Clin Chem Lab Med 47: 387-390, 2009. https://doi.org/10.1515/CCLM.2009.109

HUBACEK JA, RYNEKROVA J, KASPAROVA D, ADAMKOVA V, HOLMES MV, FAIT T: Association of MTHFR genetic variants C677T and A1298C on predisposition to spontaneous abortion in Slavonic population. Clin Chim Acta 440: 104-107, 2015. https://doi.org/10.1016/j.cca.2014.11.018

KITTNAR O: Selected sex related differences in pathophysiology of cardiovascular system. Physiol Res 69: 21-31, 2020. https://doi.org/10.33549/physiolres.934068

MALASSINÉ A, CRONIER L: Involvement of gap junctions in placental functions and development. Biochim Biophys Acta 1719: 117-124, 2005. https://doi.org/10.1016/j.bbamem.2005.09.019

MESSNER B, BERNHARD D: Smoking and cardiovascular disease: mechanisms of endothelial dysfunction and early atherogenesis. Arterioscler Thromb Vasc Biol 34: 509-515, 2014. https://doi.org/10.1161/ATVBAHA.113.300156

OLIVER-WILLIAMS CT, HEYDON EE, SMITH GC, WOOD AM: Miscarriage and future maternal cardiovascular disease: a systematic review and meta-analysis. Heart 99: 1636-1644, 2013. https://doi.org/10.1136/heartjnl2012-303237

PECORARO M, VERRILli V, PINTO A, POPOLO A: Role of connexin 43 in cardiovascular diseases. Eur J Pharmacol 768: 71-76, 2015. https://doi.org/10.1016/j.ejphar.2015.10.030

PIŤHA J, HUBÁČEK JA, PIŤHOVÁ P: The connexin 37 (1019C>T) gene polymorphism is associated with subclinical atherosclerosis in women with type 1 and 2 diabetes and in women with central obesity. Physiol Res 59: 1029-1032, 2010. https://doi.org/10.33549/physiolres.932039

PIŤHA J, KRÁLOVÁ LESNÁ I, HUBÁČEK JA, SEKERKOVÁ A, LÁNSKÁ V, ADÁMKOVÁ V, DOROBANTU M, NICOLESCU R, STEINER R, IVIĆ V, BORBELY A, PAPP Z, SANDOR GV: Smoking impairs and circulating stem cells favour the protective effect of the $\mathrm{T}$ allele of the connexin37 gene in ischemic heart disease A multinational study. Atherosclerosis 244: 73-78, 2016a. https://doi.org/10.1016/j.atherosclerosis.2015.11.007

PIŤHA J, PIŤHOVA P, STAVEK P, HUBACEK J, AUZKY O, NESKUDLA T, PELIKANOVA T, KVAPIL M: Gene for connexin 37 is associated with atherosclerotic changes in women with diabetes mellitus type 2 . Atherosclerosis 252: 144-145, 2016b. https://doi.org/10.1016/j.atherosclerosis.2016.07.715

PITHOVA P, ŠTECHOVÁ K, PIŤHA J, LÁNSKÁ V, KVAPIL M: Determinants of preclinical atherosclerosis are different in type 1 and type 2 diabetic women. Physiol Res 65: 219-228, 2016. https://doi.org/10.33549/physiolres.933019 
RYNEKROVA J, KASPAROVA D, ADAMKOVA V, FAIT T, HUBACEK JA: Analysis of the potential role of Apolipoprotein E polymorphism in genetic predisposition to spontaneous abortion. Am J Reprod Immunol 67: 179-183, 2012. https://doi.org/10.1111/j.1600-0897.2011.01071.x

TOGASHI K, KUMAGAI J, SATO E, SHIRASAWA H, SHIMODA Y, MAKINO K, SATO W, KUMAZAWA Y, OMORI Y, TERADA Y: Dysfunction in gap junction intercellular communication induces aberrant behavior of the inner cell mass and frequent collapses of expanded blastocysts in mouse embryos. J Assist Reprod Genet 32: 6, 2015. https://doi.org/10.1007/s10815-015-0479-1

TSAI MY, LAN KC, HUANG KE, HUANG FJ, KUNG FT, CHANG SY: Significance of mRNA levels of connexin37, connexin43, and connexin45 in luteinized granulosa cells of controlled hyperstimulated follicles. Fertil Steril 80: 1437-1443, 2003. https://doi.org/10.1016/j.fertnstert.2003.05.015

VEJRAZKOVA D, VANKOVA M, LUKASOVA P, VCELAK J, CIRMANOVA V, HALUZIK M, BENDLOVA B: Specific metabolic characteristics of women with former gestational diabetes: the importance of adipose tissue. Physiol Res 66: 349-356, 2017. https://doi.org/10.33549/physiolres.933726

WONG CW, CHRISTEN T, ROTH I, CHADJICHRISTOS CE, DEROUETTE JP, FOGLIA BF, CHANSON M, GOODENOUGH DA, KWAK BR: Connexin37 protects against atherosclerosis by regulating monocyte adhesion. Nat Med 12: 950-954, 2006. https://doi.org/10.1038/nm1441 